\title{
Expression profiling of putative Eucalyptus grandis defence marker genes in response to treatment with methyl jasmonate and salicylic acid
}

\author{
Ronishree Naidoo ${ }^{1 *}$, Alexander Myburg ${ }^{1}$, Dave Berger ${ }^{2}$, Sanushka Naidoo ${ }^{1}$ \\ From IUFRO Tree Biotechnology Conference 2011: From Genomes to Integration and Delivery \\ Arraial d Ajuda, Bahia, Brazil. 26 June - 2 July 2011
}

\begin{abstract}
Background
Eucalyptus species and their hybrids encompass approximately $40 \%$ of forestry plantation area in South Africa and contribute significantly to the paper pulp industry due to their favourable wood fibre properties. Eucalypt plantation trees are affected by numerous pathogens during their lifetime, some of which can cause severe losses such as Phytophtora spp and Chrysoporthe spp. Plant defence mechanisms against pathogens is currently better understood in the model plant Arabidopsis thaliana where it has been shown that the salicylic acid (SA) and jasmonic acid (JA) signalling pathways enhance resistance against biotrophic and necrotrophic pathogens, respectively [1] . This process involves the up-regulation of specific defence genes which are considered to be marker (diagnostic) genes for the two signalling pathways $[2,3]$.
\end{abstract}

\section{Methods}

The aim of this study was to utilize the draft (8X) E. grandis genome sequence that has recently become available (http://eucalyptusdb.bi.up.ac.za) to identify Eucalyptus orthologs of defence marker genes (e.g. PR2; PR3; PR4; PR5; LOX2) specific for the SA and JA signalling pathways $[2,3]$. Bioinformatics tools were used to identify putative orthologs of these marker genes in $E$. grandis based on sequence information from other plants. This was followed by a co-phylogenetic analysis in which a neighbour-joining tree with 10000 permutations was constructed to add confidence that the correct orthologs had been identified. In the phylogenetic tree

\footnotetext{
* Correspondence: ronishree.naidoo@fabi.up.ac.za

'Department of Genetics, Forestry and Agricultural Biotechnology Institute

(FABI), University of Pretoria, South Africa

Full list of author information is available at the end of the article
}

analysis, closely related family members of a particular gene were added to increase the certainty and accuracy of selecting a specific ortholog.

The expression profile of the putative marker genes was assessed via Reverse Transcription quantitative PCR (RT-qPCR) analysis of transcript levels following treatment with various concentrations of the inducers (SA and JA) as well as different time points. This was done to confirm that the putative orthologs respond to the appropriate pathways in Eucalyptus. Additionally the expression profile of these putative orthologs was analyzed in response to the causal agent of Eucalyptus stem canker, Chrysoporthe austroafricana. The defence response of Eucalyptus to this nectrotrophic pathogen was investigated in both a tolerant (EgrTOL) and susceptible (EgrSUS) species. Changes in the level of transcript expression of the putative marker genes (PR2; PR4; PR5; LOX3) were assessed at three time points using RT-qPCR.

\section{Results and discussion}

A dose response experiment of the putative marker genes was conducted with various concentrations to elucidate which would elicit the most paramount response in gene expression. It was found that amongst the tested candidates, $5 \mathrm{mM}$ and $100 \mu \mathrm{M}$ displayed the most significant change in gene expression for SA and JA respectively (Table 1 ). The specificity of the putative markers was also determined by profiling the putative marker genes with material induced by the opposing pathway, i.e SA markers were assessed with MeJA induced material.

A time course experiment was done to investigate how the expression profiles of the genes respond over a period of time. This would shed light on a possible

c 2011 Naidoo et al; licensee BioMed Central Ltd. This is an open access article distributed under the terms of the Creative Commons Attribution License (http://creativecommons.org/licenses/by/2.0), which permits unrestricted use, distribution, and reproduction in any medium, provided the original work is properly cited. 
Table 1 Selected results from the dose response and specificity trial

\begin{tabular}{ccccc}
\hline & \multicolumn{2}{c}{ SA $(5 \mathrm{mM})$} & \multicolumn{2}{c}{ MeJA $(100 \mu M)$} \\
\hline Marker & Exp Ratio* & $\mathbf{P}$ - value & Exp Ratio* & P - value \\
\hline PR2 & 4.05 & 0.01 & -0.34 & 0.28 \\
PR3 & -4.09 & 0.03 & 0.9 & 0.05 \\
PR4 & 1.3 & 0.25 & 1.5 & 0.00005 \\
PR5 & 0.5 & 0.3 & 1.6 & 0.09 \\
LOX2 & -4.6 & 0.04 & 0.5 & 0.17 \\
\hline
\end{tabular}

*Expression ratios are represented as LOG2 values relative to the control samples

window period that one could focus on for enhancing resistance as the timing of defence is crucial in determining the outcome of a pathogen interaction. For example the PR2 gene, a marker for the SA pathway, was shown to be drastically induced at $24 \mathrm{hrs}$ followed by a decline at $48 \mathrm{hrs}$. This could be due to the fact that high levels of SA are toxic to the cell so the plant needs to closely monitor SA levels. On the other hand PR4, a marker for the JA pathway displayed a gradual increase over time beginning at $6 \mathrm{hrs}$ and peaking at $48 \mathrm{hrs}$.

When the putative marker genes were assessed in tissue infected with Chr. austroafricana, it was observed that role of SA could potentially have a crucial role in determining the outcome of the infection. It is interesting to note that at two weeks there is no significant difference in lesion length between EgrSUS and EgrTOL. In EgrTOL, the expression level of PR2 was significantly up-regulated at two weeks post-inoculation whereas EgrSUS had significantly altered levels of expression only at six weeks. However in EgrSUS, the level to which PR2 is induced is still lower than in EgrTOL. At two weeks and six weeks there is an increase in PR4 transcript levels in EgrSUS. This could explain the inability of EgrSUS to accumulate SA due to the antagonistic relationship between the two pathways which is in accordance to what is currently known in Arabidopsis [1].

\section{Conclusion}

The genes identified in this study were tested as a diagnostic tool for the screening of pathogen challenged eucalypt plant to determine which signaling pathway(s) were playing a role in defence against various pathogens. It was found that SA could potential play a role in enhancing resistance to Chr. austroafricana. Future work would involve studying the expression profile of these genes in response to various other pathogens as well as to elucidate more putative marker genes. This research provides a platform from which to expand our knowledge of plant defence in Eucalyptus and work towards curbing tree diseases.

\section{Author details}

'Department of Genetics, Forestry and Agricultural Biotechnology Institute (FABI), University of Pretoria, South Africa. ${ }^{2}$ Department of Plant Science, Forestry and Agricultural Biotechnology Institute (FABI), University of Pretoria, South Africa.

Published: 13 September 2011

References

1. Pieterse C, Leon-Reyes A, Ent S: Networking by small-molecule hormones in plant immunity. Nature 2009, 5:308-316.

2. Boter M, Ruiz-Rivero O, Abdeen A: Conserved MYC transcription factors play a key role in jasmonate signaling both in tomato and Arabidopsis. Genes Dev 2004, 18:1577-1591.

3. Mishina T, Zeier J: Pathogen-associated molecular pattern recognition rather than development of tissue necrosis contributes to bacterial induction of systemic acquired resistance in Arabidopsis. Plant J 2007, 50:500-513.

doi:10.1186/1753-6561-5-S7-P96

Cite this article as: Naidoo et al:: Expression profiling of putative Eucalyptus grandis defence marker genes in response to treatment with methyl jasmonate and salicylic acid. BMC Proceedings 2011 5(Suppl 7): P96.

\section{Submit your next manuscript to BioMed Central} and take full advantage of:

- Convenient online submission

- Thorough peer review

- No space constraints or color figure charges

- Immediate publication on acceptance

- Inclusion in PubMed, CAS, Scopus and Google Scholar

- Research which is freely available for redistribution

Submit your manuscript at www.biomedcentral.com/submit
Ciomed Central 